Journal of Business and Tourism

Volume 07 Number 01

January - June, 2021

\title{
Corporate Governance Characteristics and Environmental, Social \& Governance (ESG) Performance: Evidence from the Banking Sector of Pakistan
}

\author{
Samina Rooh \\ Lecturer, Ph.D. Scholar, Department of Management Sciences \\ University of Buner, Pakistan \\ samina.ali.bangash@gmail.com \\ Muhammad Zahid \\ Associate Professor, City University of Science and IT, Peshawar, Pakistan \\ mianmz11@gmail.com \\ Muhammad Farooq Malik \\ Independent Researcher \\ muhammad.farooq@wlcb.co.uk \\ Muhammad Tahir \\ Assistant Professor Department of Economics and Business Administration \\ Division of Management \& AdministrationScience \\ University of Education Lahore, Pakistan \\ drtahirkhan@ue.edu.pk
}

\begin{abstract}
The purpose of the paper is to examine the impact of corporate governance on environmental, social, and governance (ESG) performance.This paper alsoinvestigates the influence of corporate governance on environmental, social, and governance (ESG) disclosure.The majority of previous empirical research studies have either centered on ESG disclosure in developed economies, but the present problem concerning the corporate sector is defining the role of corporate governance in improving ESG performance inthe banking sectors of Pakistan.This paper is based on quantitative and secondary data approaches. The datawas collected fromthe annual reportsof 17 public and privatecommercial banks of Pakistan through an adapted ESG index. This study applied the Stata 13.0 panel data approach to analyzing the effect of corporate governance on ESG performance. Theresults showed that gender diversity, board independence, and return on assets(ROA) positively affect ESG performance. The board size and firm size havean insignificant impact on the ESG performance. Furthermore, firm age and previous year ESG practices (lag of ESG) have a significant positive role in the improvement of ESG performance. However, in contrast, firm leverage has a negative significant effect on the ESG practices of the banking sectors. This papertries to fulfill the gap by examiningcorporate governance and ESG performance in the banking sectors
\end{abstract}


ofPakistan. The findings of the study have significant implications for the top management of the banks, financial experts, regulatory bodies, investment advisors, academics practitioners, and Pakistan stock exchange towards the better implementation of corporate goverance and ESG practices.

\section{Keywords: Corporate Governance Characteristics,ESG performance, Banking Industry, Developing Country}

\section{Introduction}

In the previous twenty years' consideration toward issues identified with corporate governance has been growing because of sequences of financial and economic occasions happening around all over the world. According toSolomon (2020)financial crisis, high profile financial scandals, and unanticipated corporate failure have determined countries to support their corporate laws to raise confidence in financial markets.Corporate governance, according to Vo and Nguyen (2014), is concerned with relationships between the company's controlling system, board leaders' functions, investors, shareholders, and stakeholders. It also includes the structures and procedures that govern how businesses operate and how organizations are managed.According to Crifo, EscrigOlmedo,\& Mottis (2019), corporate governance is the cornerstone for a company's longterm sustainability, decision criteria in a business, and basis for performance.CG is a framework and system of management, controlling, and directing businesses and organizations (Al-ahdal, Alsamhi, Tabash, \& Farhan, 2020).Pacy \& Sifuna (2012)elucidated thatthe problem of corporate governance was highlighted following the collapse of Enron and WorldCom, two prominent U.S. firms, in 2002 and the East Asian financial crisis, and an Act called Sarbanes-Oxley was passed, emphasizing corporate governance's role in the prevention of financial embezzlement, fraud, and administrative delinquencies.Corporate governance is critical to the long-term sustainability of financial markets and, as a result, improves company success(Rooh et al., 2021).

Corporate sustainability is another apprehension of contemporary-day organizations(Zahid et al., 2018). As indicated by Aras,\& Crowther (2009) and Blowfield, \& Murray (2008) recommends that bothsustainability and corporate governanceare fundamental for the consistent activity of any company and that subsequently, much consideration ought to be paid to these ideas and their applications. They also sharp out that the idea of sustainabilityis less clear than the notion of corporate governance, which is well recognized. Good corporate governance is normallyanticipated to have asignificant positive influence on the sustainability presentation execution, revelation, and disclosure (Bebbington, Larrinaga, \& Moneva, 2008).Nowadays, companies set upcorporate governance and corporatesustainability into business practice to accomplish a competitive advantage over opponents(Mahmood, Kouser, Ali, Ahmad, \& Salman, 2018).Differentnations and strategycreators have also begun advancing these ideas together.According to Ghosh 
(2017), corporatesustainability(CS) and corporate governance (CG) are meeting through the thought of the "triple-bottom-line" in the corporate meeting room. Throughout sustainability disclosures, companies are representing their sustainability governance and presentation. However, given the acknowledgment of the presence of the connection between these two ideas and given the way that guidelines creators are suggesting new instruments (e.g., CSR panel) for guaranteeing superior governance and sustainability, there is an absence of research that empirically looks at the influence of various corporate governance components on the various elements of corporate sustainability reporting.

As a result of these transformations, empirical studies have begun to focus on the level of disclosure of environmental, social, and governance (ESG) initiatives implemented by companies.A company's ESG activities are significant because both institutional and individual investors comprehend that ESG indicates the company's possibilities and hazards(Lagasio \& Cucari, 2019; Limkriangkrai, Koh,\& Durand, 2017).Despite the reality that ESG disclosure is mandatory (Cucari, Esposito de Falco, \& Orlando, 2018), every business should disclose its ESG activities to its stakeholders since greater accountability leads to greater financial gain(Dellaportas, Langton, \& West, 2012).Environmental (for example, climate change), social responsibility (for example, human rights), and corporate governance are all examples of ESG (e.g., shareholder protection).In regarding financial performance, ESG has become a leading indicator of non-financial performance(Boerner, 2011; Galbreath, 2013). There has been worldwide dissemination of reporting standards(Ioannou,\& Serafeim, 2017). This research looked into the effects of corporate governance on ESG performance in the Pakistani banking sector to fill this gap.

Non-financial performance indicators, such as Environmental, Social, and Governance (ESG) measures, are potentially driving predictors of a firm's financial performance, according to (Khan, 2019). This studyexamines earlier scholarly work and also the notion of ESG materiality in order to build innovative corporate governance and ESG indicators.

Customers, personnel, open special interests, and regulatory agencies have all showed interest as to how an organization's performance on environmental, social, and governance (ESG) issues has been growing.As a result of the examination, companies have attempted inside activities to increase performance on ESG problems, targeted nonbargain the executive's street engagements with investors to emphasize their ESG procedures, and openly highlighted their ESG efforts in their financial reports. In the context of this, investors have challenged whether ESG performance affects stock returns(Khan, 2019).Rooh et al. (2021) elucidated that company governance advocacy agencies have considered ESG issues in their decision-making of investment.

The current problem for the corporate sector is to clearly define the function of corporate governance in enhancing ESG in Pakistan's financial sectors. Despite the fact that numerous studies have been conducted on corporate governance in the non- 
financial sector and other problems, only a few have investigated the effect of corporate governance on ESG performance.Nonetheless, there are only a few published studiesthat examine the impact of corporate governance on ESG performance in Pakistan's banking sector(Lagasio, \&Cucari, 2019). Crifo, Escrig-Olmedo, \& Mottis(2019)In France, corporate governance was evaluated as a significant driver of economic sustainability.andShakil, Tasnia, \& Mostafiz(2020)examined the relationship between board gender diversity and the performance of US banks in terms of the environment, social, and governance issues: the moderating effect of environmental, social, and corporate governance controversies

The study's objective is to look into the influence of corporate governance on ESG performance and the research question is: What is the influence of corporate governance on ESG performance?

The study will add to the extended discussion on corporate governance systems that lead to improved ESG performance and reinforces the need for a modern take on these problems. As a result, this research contributes to the existing literature by fulfilling a gap in knowledge. From numerous perspectives, this paper adds to the nonfinancial reporting literature. This research provides additional transparency to the relationship between corporate governance and ESG transparency. In reality, policymakers have been calling for greater concernabout the critical role of business construction in improving non-financial reporting in recent years.

\section{REVIEW OF LITERATURE}

\subsection{Theoretical Framework}

The board of directors is regarded as the most important component affecting the company and the interests of the owners in corporate governance. In that position, the issue of "but what were the features of a board of directors and how to do these impact a firm's performance" has attracted the curiosity of academics and researchers over the past fifty years or so.Zahra, \& Pearce(1989)observed the role of a board of directors on financial performance by measuring and participatingin four viewpoints: (i) agency theory (ii) Stakeholder Theory, and. In the meantime, stewardship theory, which explained the board's responsibility in a variety of ways (Davis, Schoorman, \& Donaldson, 1997).

\subsubsection{Agency Theory}

This theory is seen to be the most significant in describing how board directors influence business success. This theory proposed that there is a difference between the benefits of principals and agents. Zahra, \& Pearce (1989)havinga similar view on agency theory. The owner has the propensity to increase the benefit of shareholders in the future. On the other hand, the manager tends to workwith firms for their interests. (Khan, Arifur., Muttakin, Mohammad Badrul., and Siddiqui, 2013) discovered that by appropriately designing the mechanism and practice of corporate governance, the agency cost can be reduced. Elghuweel, et al.,(2016) discovered that managers take 
advantage of the resources of concerned corporations more than the firm's needs.According to Filatotchev and Boyd (2009), corporate governance is controlled by goals and objectives, including the protection of shareholders' interests and the alignment of interests between the principal party and the agent.According to Erkens(2009), agency theory serves as a check on management's evil schemes, compelling them to work in the best interests of the shareholders. This is based on the reality that the principal and the agent have an inherent conflict of interest. When management (agent) fails to make judgments that are in the best interests of the shareholders, a conflict between Principal and Agent occurs (principal). The management offers benefits to itself (agent) at the expense of the shareholder's benefits (principal).

\subsubsection{Stakeholder Theory}

This theory was planned in the book, "Strategic Management" by R. Edward Freeman. Stakeholder theory is awarded to him like the father.ByPost, Preston, \& Sauter-Sachs (2002), this is a system of organizational management that covers ethical principles in organizational management as well as dominating corporate values.Ordinary stakeholders incorporate suppliers, employees, consumers, creditors, government, communities, and shareholdersincluding the limits of a business's activities(Zahid et al., 2020). The stakeholder theory offersto underpin to any studyassociated to business stakeholders and society. The theory proposes that as companies are part of society, they have a responsibility to compensate for the damage they cause by making a lot of noise and polluting the environment (Freeman, 1984). The theory suggests that an organization's success and long-term sustainability are determined largely by how well it serves its stakeholders. This new trend is expanding companies' obligations by moving their focus from mainly on shareholders to a broad range of stakeholders. The author elucidated that stakeholders are the individuals, who are affected or will be affected by an organization's operations. As a result, the stakeholders include the government, society, and the general public, and also shareholders, creditors, employees, suppliers, and the natural environment.As a consequence, companies must consider the interests of shareholders whilst emphasizing the well-being of individuals and society (Donaldson, \& Preston, 1995).The stakeholder theory's descriptive approach assumes a strategic approach toward stakeholder satisfaction as well as the maximization of shareholder wealth.

\subsection{Empirical Studies}

\subsubsection{Gender Diversity}

The composition of the management board is the most critical factor impacting ESG performance in corporate governance (Velte, 2016).The background, psychological characteristics, and experience of female board members influence their participation in strategic decisions that affectstakeholdersand banks' ESG performance (Manita, Bruna, 
Dang,\& Houanti, 2018).The resource dependence theory can explain board gender diversity andESGperformance. According to resource dependence theory, board members' important resources, Like the background, psychological attributes, and capability, have such an effect on the company(Kyaw, Olugbode, \& Petracci, 2017; Manita, Bruna, Dang,\& Houanti, 2018).Furthermore, some research looks into the sound effects of board gender diversity on firm ESG performance \&discovers both a positive and negative influence(Arayssi, M., Jizi, M., \& Tabaja, 2020; Cucari, N., Esposito de Falco, S., \& Orlando, 2018; Husted, B.W. and Sousa-Filho, 2019; Zahid et al., 2019).

\subsubsection{Board Independence}

Within and outside directors, according to Bhagat, \& Black (2000)have distinct attributes. Outsiders, such as affiliated directors, could provide a wide range of experience, abilities and capabilities to the panel, Insiders, on the other hand, might also be desirable at organizing\& deciding when it comes to decision-making. The board's combined abilities may lead to excellent business performance.Inside and outside executives as facilitators of board arrangement on financial success was the basis of a study led by(Klein, 1998). To find the difference in company performance affected by board composition and director motivating drivers, Hermalin, B. E., \& Weisbach(1991)used a tool method to discard false connections among dependent and independent variables.According to the findings, do both within and outside executives have a similar impact on firm execution?Furthermore, because each board of directors in each corporation has an ideal structure that includes both within and external directors, it is challenging to predict that has a significant association between board composition business success. Every organization strives to keep agency costs as low as possible.

\subsubsection{Board Size}

The board's main duties, according to the agency theory, are to regulate management's operations in order to make sure the company's integrity, objectivity, accountability, and transparency(Hegazy, M., \& Hegazy, 2010; Rahman, Zahid, \& Khan, 2021). Transparency in the boardroom improves with a larger boardLevit, \& Malenko (2016)argue that it is more efficient since it has a wider range of knowledge, skills, and capacities to monitor and supervise the organization's actions(Almutairi, \& Quttainah, 2017; Tawfeeq et al., 2019).on the other sideAdnan, Htay, Rashid, \& Meera(2011)A larger board is inefficient due to the slow nature of decision-making, which makes achieving corporate consistency difficult.Board's primary job, according to Al Azeez, Sukoharsono, \& Andayani ( 2019), is to oversee the firm's internal and external operations to create positive outcomes. The next step is to assess the administration's performance. It contributes to the company's growth, drives management toward certain goals, and communicates the major goals of the firms.In addition, by agency theory, the board size has an influence on the organizational environment. The first benefit of a 
larger board is that it can handle more challenges, and the second benefit is that it can broaden the organization's impact on society because of the relationships among board members.Consequently, businesses with a large number of directors will waste a bigger amount of assets from the outside rather than improving their performance.

\subsubsection{Firm Age}

Another independent variable included in this study is firm age, and there are two perspectives on how to measure firm age. The first group believes that counting a firm's age from the date of its stock market listing, as advocated byFama, \& French (2004), will change ownership building and increase development,chances.The second group advocates that firms' ages be calculated from their commencement date; proponents of this position compriseLoderer, \& Waelchli(2010), who feel that firm age is related to lawful entities and market knowledge.This author agrees with the second viewpoint, hence the current study practicessimilar criteria to determine the firm's age, that is the sum of years from its foundation to 2018. The study's definition of firm age is as under.

Firm Age = the periodfrom the company's foundation to the year 2018.

\subsubsection{Firm Size}

have that the size of a company has a significant influence on its success and is linked to a range of corporate characteristicsdiscovered by Numerous research studies. In this study,firm size is used as an independent variable to see how closely board structure and firm performance are linked.According toAl-kake, \& Ahmed (2019),firm size has a substantial impact on board structure decisions, and they also believe that firm size is linked to a company's market growth potential.The firm size will be measured in this study in the same way that it was inAl-Matari, et al. (2012)did (1998). They computed a firm's size that uses the natural logarithm of its total assets and using firm size as a controlling variable. The size of the firm, on the other hand, will be used as a normal independent variable in this study because, at the end of the day, it is the size of the firm that concerns, it is still an independent variable, even if it is used as a dependent variable.

\section{Firm Size $=$ the logarithm of a company's total assets}

\subsubsection{Firm Leverage}

Firm leverage also referred to as financial leverage, is stated as the debt-to-total-assets ratio.according to Weill (2005), Shareholders borrow money to invest in securities, which is known as firm leverage. The leverage of a company is measured in percentages (Rahman, Zahid, \& Muhammad, 2021; Yolanda \& Utama, 2021).

Many research publications have employed company leverage to examine the link between corporate governance and business presentation. Other academic research, such as Bhagat, \& Black (2000), have employed firm leverage as a normal independent variable (2008). As a research method, leverage will be used: 


\section{Firmleverage $=$ TotalFirmAssets $/$ TotalEquit}

\subsubsection{Return on Assets}

The proportion derived by dividing a company's net profit by its total assets is called a return on assets. The formula for ROA is as follows:

ROA $=$ NetProfit $/$ TotalAssets $\times 100$

\subsection{Conceptual Framework}

Independent Variables

\section{Variable}

Dependent

\begin{tabular}{|c|c|c|}
\hline Corporate Governance & \\
$\circ$ & Gender Diversity \\
$\circ$ & Board Independence \\
$\circ$ & Board Size \\
$\circ$ & Firm Age \\
$\circ$ & Firm Size \\
$\circ$ & Firm Leverage \\
$\circ$ & Return on Assets & \\
Environmental, \\
Social, \& \\
Governance (ESG) \\
\\
\hline
\end{tabular}

The following set of hypotheses are based on the theoretical framework derived from the literature review:

$\mathrm{H}_{1}$ : Gender Diversity has a significant impact on ESG Performance in the banking sectors of Pakistan.

$\mathrm{H}_{2}$ : Board Independence has a significant impactonESG Performance in the banking sectors of Pakistan.

$\mathrm{H}_{3}$ : Board Size has a significant impact on ESG Performance in the banking sectors of Pakistan.

$\mathrm{H}_{4}$ : Firm Age has a significant impact on ESG Performance in the banking sectors of Pakistan.

$\mathrm{H}_{5}$ : Firm Size has a significant impact on ESG Performance in the banking sectors of Pakistan.

$\mathrm{H}_{6}$ : Firm Leverage has a significant impact on ESG Performance in the banking sectors of Pakistan.

$\mathrm{H}_{7}$ : Return On Assets has a significant impact on ESGPerformance in the banking sectors of Pakistan.

\section{Data and Methodology}


The current research is empirical in nature, therefore it looked at financial data from both public and private institutions. Since descriptive statistics were used, the variables measurement and quantitative research technique were deductive and aimed to evaluate hypotheses and theoretical assumptions. The goal of the paper is to see how corporate governance influences ESG performance in the banking sector on the Pakistan Stock Exchange. The population of the current study is made up of both public and private banks, and the sample size is balanced. This research isgroundedon secondary data, thedata for ESG has been composed using the index(Zahid et al., 2018), while secondary data for corporate governance has been gathered from the annual reports of the selected banksregistered on the Pakistan Stock Exchange, and the State Bank of Pakistan.Pakistan Stock Exchange has 34 public and private sector banks listed by 2020. In 2020 NBP, HBL, and UBL declared that Pakistan's banking system is made up of commercial banks, foreign banks, Islamic banks, development financial institutions, and microfinance banks. There are around 31 banks in the industry, with five public sector banks, 22 private banks, and four international banks. The population includes all 31 Public and Private Sector banks. This study has been taken 17 commercial banks as a sample. The purposive sampling technique, Stata 13.0 has been employed to analyze the data. The influence of corporate governance on ESG performance has been examined with the help of correlation relation analysis.

\section{4:Data Analyses and Results}

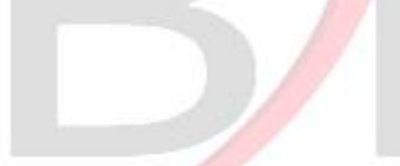

Table 1: Descriptive Statistics

\begin{tabular}{|c|c|c|c|c|c|c|c|c|}
\hline & \multirow{2}{*}{$\begin{array}{c}\text { Min } \\
\text { Statistic }\end{array}$} & \multirow{2}{*}{$\begin{array}{c}\text { Max } \\
\text { Statistic } \\
\end{array}$} & \multirow{2}{*}{$\begin{array}{c}\text { Mean } \\
\text { Statistic }\end{array}$} & \multirow{2}{*}{$\begin{array}{l}\text { Std. Dev. } \\
\text { Statistic }\end{array}$} & \multicolumn{2}{|c|}{ Skewness } & \multicolumn{2}{|c|}{ Kurtosis } \\
\hline & & & & & Statistic & S.E & Statistic & S.E \\
\hline ESG & 13 & 50 & 28.80 & 13.092 & .440 & .337 & -1.373 & .662 \\
\hline Gender Diversity & .0000 & .8000 & .124 & .223 & 2.256 & .337 & 4.530 & .662 \\
\hline Board Independence & .200 & .666 & .279 & .082 & 2.707 & .337 & 9.328 & .662 \\
\hline Board Size & 6 & 13 & 9.78 & 1.951 & .443 & .337 & -.681 & .662 \\
\hline Firm Age & 15 & 75 & 43.60 & 22.539 & .076 & .337 & -1.911 & .662 \\
\hline Firm Size & 274437 & 2400000 & 893015.18 & 529690.907 & 1.004 & .337 & .320 & .662 \\
\hline Firm Leverage & .762 & 1.062 & .854 & .024 & .174 & .337 & .421 & .662 \\
\hline Return on Assets & -.013 & .062 & .014 & .023 & .230 & .337 & -.421 & .662 \\
\hline
\end{tabular}

Table 1 shows ESG has minimum and maximum values of 13 and 50 respectively. The mean value of ESG is 28.80. The minimum value of gender diversity is 0.000 and the maximum of .800 . The mean value of gender diversity is .124 . Board independence shows .200 minimum and .666 maximum values respectively. Likewise, the mean value is .279. The board size shows a minimum of 6 and a maximum value of 13 , while the mean value is 9.78 . The control variables having the mean value of 43.60 for firm age, 0.854 for firm leverage, and 0.014 for return on assets. 
Table 2: Pearson's Correlation Matrix

\begin{tabular}{lcccccccc}
\hline & $(1)$ & $(2)$ & $(3)$ & $(4)$ & $(5)$ & $(6)$ & $(7)$ & $(8)$ \\
\hline ESG (1) & 1 & & & & & & & \\
Gender Diversity (2) & 0.215 & 1 & & & & & & \\
Board Independence (3) & $-.532^{* *}$ & 0.016 & 1 & & & & & \\
Board Size (4) & 0.077 & $.306^{*}$ & -0.180 & 1 & & & & \\
Firm Age (5) & 0.242 & -0.277 & $-.354^{*}$ & -0.029 & 1 & & & \\
Firm Size (6) & 0.086 & -0.109 & $-.442^{* *}$ & -0.079 & $.821^{* *}$ & 1 & & \\
Firm Leverage (7) & -0.251 & 0.041 & $.405^{* *}$ & $.296^{*}$ & $-.407^{* *}$ & $-.362^{* *}$ & 1 & \\
Return on Assets (8) & $.513^{* *}$ & -0.105 & $-.501^{* *}$ & -0.234 & $.489^{* *}$ & $.366^{* *}$ & $-.796^{* *}$ & 1 \\
\hline
\end{tabular}

**. Correlation is significant at the 0.01 level (2-tailed).

*. Correlation is significant at the 0.05 level (2-tailed).

Pearson's correlation identifies the problem of multicollinearity. Table 2 shows that the maximum value of correlation is -0.532 which is below the maximum limit of .85 , hence, there is no issue of multicollinearity.

\section{1: Findings and Discussion}

The regression analysis for the hypotheses reports in the following Table 3.

\section{Table 3: Regression Analysis}

\begin{tabular}{|c|c|c|c|}
\hline & $\begin{array}{c}\text { (OLS) } \\
\text { ESG }\end{array}$ & $\begin{array}{c}\text { (GLS-RE) } \\
\text { ESG }\end{array}$ & $\begin{array}{c}\text { (GLS-FE) } \\
\text { ESG }\end{array}$ \\
\hline Gender Diversity & $\begin{array}{c}1.308^{* * *} \\
(.39)\end{array}$ & $\begin{array}{c}1.308^{* * *} \\
(.39)\end{array}$ & $\begin{array}{c}.523^{* * * *} \\
(.185)\end{array}$ \\
\hline Board Independence & $2.811^{* *}$ & $2.811^{* *}$ & 2.048 \\
\hline Board Size & $\begin{array}{c}(1.374) \\
-.043\end{array}$ & $\begin{array}{c}(1.374) \\
-.043\end{array}$ & $\begin{array}{c}(2.172) \\
.077\end{array}$ \\
\hline Firm Age & $\begin{array}{l}.303^{*} \\
(.174)\end{array}$ & $\begin{array}{l}.303^{*} \\
(.174)\end{array}$ & $\begin{array}{l}.962^{* *} \\
(.382)\end{array}$ \\
\hline Firm Size & $\begin{array}{l}-.269 \\
(.187)\end{array}$ & $\begin{array}{l}-.269 \\
(.187)\end{array}$ & $\begin{array}{c}-.29 \\
(.196)\end{array}$ \\
\hline Firm Leverage & $\begin{array}{c}.484 * * * \\
(.146)\end{array}$ & $\begin{array}{c}.484 * * * \\
(.146)\end{array}$ & $\begin{array}{c}.124 \\
(.142)\end{array}$ \\
\hline Return on Assets & $\begin{array}{c}.594 * * * \\
(.159)\end{array}$ & $\begin{array}{c}.594 * * * \\
(.159)\end{array}$ & $\begin{array}{l}-.057 \\
(.114)\end{array}$ \\
\hline Lag of ESG & $\begin{array}{c}.515^{* * *} \\
(.099)\end{array}$ & $\begin{array}{c}.515^{* * *} \\
(.099)\end{array}$ & $\begin{array}{l}.128^{* *} \\
(.061)\end{array}$ \\
\hline Constant & $\begin{array}{c}.726 \\
(.735)\end{array}$ & $\begin{array}{c}1.05 \\
(.759)\end{array}$ & $\begin{array}{l}-1.374 \\
(1.609)\end{array}$ \\
\hline Observations & 49 & 49 & 49 \\
\hline R-squared & .8 & .80 & .758 \\
\hline Years Dummies & Yes & Yes & Yes \\
\hline Hausman Test (Chi2) & - & 6.67 & - \\
\hline Prob. > Chi 2 & - & .453 & - \\
\hline
\end{tabular}


The research analyzes the impact of corporate governance on the ESG policies of Pakistan's banking industry using the panel data random-effect (RE) and fixed-effect (FE) models of the Generalized Least Squares (GLS). Furthermore, the study also robust the results using ordinary least squares (OLS) estimator. The GLS random-effect as recommended by the Hausman test (Prob. Chi2 $=0.453$ ) reported in Table 4 shows that gender diversity has a significant positive impact on the ESG practices which supports hypothesis 1 of the study. The findings are in line with the previous studies Lagasio, \& Cucari (2019); Garde Sánchez et al. (2017);Majumder, Akter, \& Li (2017);Liao, Luo, \& Tang (2015).Similarly, board independence has also a significant positive impact on the ESG practices of sample banks and supported hypothesis 2 of the study. Results are consistent with the results of Lagasio, \& Cucari (2019);Majumder, Akter, \& Li (2017);Liao, Luo, \& Tang (2015) However, in contrast, board size has no impact on ESG practices and hence, rejected hypothesis 3 of the study. The finding of the previous study is similar toAslam \& Haron(2020). This is in no line with earlier academic outcomes by Garde Sánchez et al. (2017; Giannarakis (2014); and Majeed, Aziz, \& Saleem (2015).In the control variables firm age, return on assets, and previous year ESG practices (lag of ESG) have a positive role in the improvement of ESG standards and supports hypotheses 4, 7, and 8 of the study. The findings are the same as the results of Hossain et al. (2016), and in contrast, the result is insignificant (Al-Kake \& Hamawandy, 2019). However, in contrast, firm leverage has a significant negative effect on the ESG practices of the sample banks and hence, supports hypothesis 6 of the study. Hence, The results are in line with the prior studies of(Al-Kake \& Hamawandy 2019); and (Rooh,\& Malik, 2021). The findings further noted the insignificant impact of firm size on the ESG practices and hence not supported hypothesis 5 of the study. The study is not consistent with (Garde Sánchez et al., 2017); and(Al-Kake \& Hamawandy, 2019).

\section{Conclusion and way forward}

This research examines the specific characteristics of the CG of banks about the reporting of ESG practices that the banking sector engages in. This study builds on prior research on the evolution of ESG standards in Pakistan's banking sector. Outcomes-based on the Stata analysis showing that variables that are positively linked with the degree of disclosures are Gender Diversity, Board Independence\& Return on Assets. Gender Diversity and Board Independence suggests that the greater the size of a firm's or bank's board independence, the greater the degree of ESG disclosure. This research also shows that firm leverage and ESG practices have a substantial negative relationship.As a result, there is no link between company leverage and ESG performance. In addition, the results of board size and firm size had little bearing on the bank's ESG practices. Firm age, return on assets, and previous year ESG practices (lag of ESG) all show a positive role in the improvement of ESG practices in the control variables. This confirms that the longer a company has been in business and the higher its profitability, the more participation, improvement, and support it receives for ESG operations. ESG Disclosure, on the other 
hand, can be used to entice institutional investors to invest actively in firms that have well-established ESG platforms. As can be seen from the aforementioned findings, this study has a variety of potential implications for the CG and ESG literature. First, this study provided insight into firms'/banks' CG and ESG reporting practices, expanding on earlier work that had mostly focused on ESG practices.As a result, it offers up new research opportunities to compare and contrast these findings with corporations from other developing and developed countries' stock exchanges. Second, the earlier CG and ESG study has been expanded to include the Pakistani industry.Third, our research adds to the current ESG literature by demonstrating that the inclusion of female board members and board independence has a significant impact on bank ESG performance.Regulators, users of bank annual reports, and foreign researchers will be interested in the conclusions of this study. The result gives stakeholders, especially shareholders, significant insight into the bank's ESG performance and helps them comprehend how CG affects the ESG operations of banking sectors. The outcomes will help regulators tighten corporate governance policies, which will improve bank accountability and increase female representation on bank boards. It also requires banks to adhere to good governance practices. The findings will aid the Securities and Exchange Commission in establishing an acceptable ESG policy.The regulation will serve as a guide for the listed banks, and any violation of the rule's structure will result in a specified punishment for the banks.

Even though this study has significant practical consequences, the study also delivers practical understandings to public and private listed companies, regulators, and practitioners on how to increase the representation of women directors on boards of directors, as well as improve compliance with economic, environmental, and social sustainability disclosures, through effective participation of women directors on boards. These, in turn, are expected to add to the company's existing development goals. The study's practical implications also include that the financial sector of any country plays a significant role in the nation's prosperity, and similarly, corporate governance plays an important role in the organizations' prosperity; they are interconnected in this regard. Managers carry full responsibility in this case, and they should emphasize corporate governance and ESG performance in Pakistan's banking sector.The research reveals that agency problems influence managers' decisions about corporate governance and ESG disclosure and that it has a significant impact on firm performance in terms of agency costs. To improve firm ESG performance, managers should minimize agency costs, which could only be achieved if they establish a strong corporate governance structure in the workplace.

The major limitation of the research isthe lack of ESG data the study only analyzed commercial banks. As a result, investment banks and Securities and Exchange Commission businesses registered on the Pakistan Stock Exchange were excluded from the study.Data collecting was a time-consuming and labor-intensive task. The researcher had much trouble obtaining data for specific factors and had to visit many financial 
institutions. Furthermore, the delimitation of the study is that it covers all banking sectors in Pakistan rather than also commercial banks. Similarly, the second delimitation of the study is that data of banking sectors will be collected from annual reports and the state bank of Pakistan for 10 years.

The current study focused on corporate governance's internal mechanisms and ESG practices, while future research may look at the external mechanisms of corporate governance. Further research should investigate a larger sample size and representation from industries other than banking.Future research should look into the intersection of corporate governance and other sub-factors.By pursuing a relative examination of corporate governance procedures amongst different financial and non-financial organizations, the current study could be extended to additional stock exchanges around the world by a future researcher.Future research could look into the impact of corporate governance and environmental, social, and governance (ESG) on conventional and Islamic banks listed on the Pakistan stock exchange. Future research should further look into the impact of board qualities on ESG performance by including different Pakistani banks, financial institutions, and non-financial institutions.

\section{References}

Adnan, M. A., Htay, S. N. N., Rashid, H. M. A., \& Meera, A. K. M. (2011). A panel data analysis on the relationship between corporate governance and bank efficiency. Journal of Accounting, 1(1), 1-15.

Al-kake, F., \& Ahmed, D. M. (2019). The role of the Sarbanes-Oxley Act (SOX) in Reducing Agency Costs. Qalaai Zanist Scientific Journal,4(2), 637-673.

Al-Kake, F., \& Hamawandy, N. M. (2019). The Effect of Corporate Governance on Firm's Profitability: Evidence from London Stock EXCHANGE. International Journal of Psychosocial Rehabilitation, 23(2), 727-742.

Al-Matari, E. M., Al-Swidi, A. K., Fadzil, F. H., \& Al-Matari, Y. A. (2012). The impact of board characteristics on firm performance: Evidence from nonfinancial listed companies in Kuwaiti Stock Exchange. . International Journal of Accounting and Financial Reporting,2(2), 310-332.

Al Azeez, H. A. R., Sukoharsono, E. G., \& Andayani, W. (2019). The impact of board characteristics on earnings management in the international oil and gas corporations. Academy of Accounting and Financial Studies Journal, 23(1), 1-26.

Almutairi, A. R., \& Quttainah, M. A. (2017). Corporate governance: evidence from Islamic banks. Social Responsibility Journal.

Aras, G., \& Crowther, D. (2009). Corporate sustainability reporting: a study in disingenuity? Journal of Business Ethics,87(1), 279.

Arayssi, M., Jizi, M., \& Tabaja, H. H. (2020). The impact of board composition on the level of ESG disclosures in GCC countries. Sustainability Accounting, Management and Policy Journal.

Aslam, E., \& Haron, R. (2020). Does corporate governance affect the performance of Islamic banks? New insight into Islamic countries. Corporate Governance (Bingley), 20(6), 10731090. https://doi.org/10.1108/CG-11-2019-0350 
Bebbington, J., Larrinaga, C., \& Moneva, J. M. (2008). Corporate social reporting and reputation risk management. Accounting, Auditing \& Accountability Journal,21(3), 337-361.

Bhagat, S., \& Black, B. (2000). Board independence and long-term firm performance. Unpublished paper, University of Colorado.

Blowfield, M., \& Murray, A. (2008). The Impact of Corporate Responsibility. ' Corporate responsibility: a critical introduction. Oxford.

Boerner, H. (2011). Sustainability and ESG reporting frameworks: issuers have GAAP and IFRS for reporting financials-what about reporting for intangibles and non-financials? Corporate Finance Review, 15(5), 34.

Crifo, P., Escrig-Olmedo, E., \& Mottis, N. (2019). Corporate governance as a key driver of corporate sustainability in France: The role of board members and investor relations. Journal of Business Ethics, 159(4), 1127-1146.

Cucari, N., Esposito de Falco, S., \& Orlando, B. (2018). Diversity of board of directors and environmental social governance: Evidence from Italian listed companies. Corporate Social Responsibility and Environmental Management, 25(3), 250-266.

Davis, J. H., Schoorman, F. D., \& Donaldson, L. (1997). Toward a stewardship theory of management. Academy of Management Review, 22(1), 20-47.

Dellaportas, S., Langton, J., \& West, B. (2012). Governance and accountability in Australian charitable organizations: Perceptions from CFOs. International Journal of Accounting and Information Management,20(3), 238-254.

Donaldson, T., \& Preston, L. E. (1995). The stakeholder theory of the corporation: Concepts, evidence, and implications. Academy of Management Review, 20(1), 65-91.

Elghuweel, Mohamed I., Ntim, Collins G., Opong, Kwaku K., and Avison, L. (2016). Corporate governance, Islamic governance and earnings management in Oman: A new empirical insights from a behavioral theoretical framework. Journal of Accounting in Emerging Economies, 7(2), 155-216.

Erkens, H., and M. (2009). Corporate Governance in the 2007-2008 Financial Crisis: Evidence from Financial Institution Worldwide. Mashall School of Business, University of Southern California.

Fama, E. F., \& French, K. R. (2004). New lists: Fundamentals and survival rates. Journal of Financial Economics, 73(2), 229-269.

Freeman, R. E. (1984). The stakeholder theory of the modern corporation.

Galbreath, J. (2013). ESG in focus: The Australian evidence. Journal of Business Ethics, 118(3).

Garde Sánchez, R., Rodríguez Bolívar, M. P., \& López Hernández, A. M. (2017). Corporate and managerial characteristics as drivers of social responsibility disclosure by state-owned enterprises. Review of Managerial Science, 11(3), 633-659. https://doi.org/10.1007/s11846016-0199-7

Ghosh, A. (2017). Corporate governance and corporate social responsibility. In Essays on Sustainability and Management. Springer, Singapore, 153-175.

Giannarakis, G. (2014). The determinants influencing the extent of CSR disclosure. International Journal of Law and Management.

Hegazy, M., \& Hegazy, K. (2010). Corporate governance in the UK: audit committees and disclosure arrangements-a web-based analysis. Journal of Business Studies Quarterly, 1(2), 32.

Hermalin, B. E., \& Weisbach, M. S. (1991). The effects of board composition and direct 
incentives on firm performance. Financial Management, 101-112. http://dx.doi.org/10.2307/3665716.

Hossain, M. M., Alamgir, M., \& Alam, M. (2016). The mediating role of corporate governance and corporate image on the CSR-FP link: Evidence from a developing country. Journal of General Management, 41(3), 33-51. https://doi.org/10.1177/030630701604100303

Husted, B.W. and Sousa-Filho, J. M. d. (2019). "Board structure and environmental, social, and governance disclosure in Latin America", Journal of Business Research, 102, 220-227.

Ioannou, I., \& Serafeim, G. (2017). The consequences of mandatory corporate sustainability reporting. Harvard Business School Research Working Paper, 11-100.

Khan, Arifur, Muttakin, Mohammad Badrul., and Siddiqui, J. (2013). Corporate governance and corporate social responsibility disclosures : evidence from an emerging economy.Journal of Business Ethics, 114(2), 207-223.

Khan, M. (2019). Corporate governance, ESG, and stock returns around the world. Financial Analysts Journal,75(4), 103-123.

Klein, A. (1998). Firm Performance and Board Committee Structure 1. The Journal of Law and Economics,41(1), 275-304. http://dx.doi.org/10.1086/467391

Kyaw, K., Olugbode, M., \& Petracci, B. (2017). Can board gender diversity promote corporate social performance? Corporate Governance: The International Journal of Business in Society.

Lagasio, V., \& Cucari, N. (2019). Corporate governance and environmental social governance disclosure: A meta- analytical review. Corporate Social Responsibility and Environmental Management,26(4), 701-711.

Lagasio, V., \& Cucari, N. (2019). Corporate governance and environmental social governance disclosure: A meta-analytical review. Corporate Social Responsibility and Environmental Management, 26(4), 701-711. https://doi.org/10.1002/csr.1716

Levit, D., \& Malenko, N. (2016). The labor market for directors and externalities in corporate governance. The Journal of Finance, 71(2), 775-808.

Liao, L., Luo, L., \& Tang, Q. (2015). Gender diversity, board independence, environmental committee, and greenhouse gas disclosure. The British Accounting Review, 47(4), 409-424.

Limkriangkrai, M., Koh, S., \& Durand, R. B. (2017). Environmental, social, and governance (ESG) profiles, stock returns, and financial policy: Australian evidence. International Review of Finance, 17(3), 461-471.

Loderer, C., \& Waelchli, U. (2010). Protecting minority shareholders: Listed versus unlisted firms. Financial Management,39(1), 33-57.

Mahmood, Z., Kouser, R., Ali, W., Ahmad, Z., \& Salman, T. (2018). Does corporate governance affect sustainability disclosure? Mixed methods study. Sustainability,10(1), 207.

Majeed, S., Aziz, T., \& Saleem, S. (2015). The effect of corporate governance elements on corporate social responsibility (CSR) disclosure: An empirical evidence from listed companies at KSE Pakistan. International Journal of Financial Studies,3(4), 530-556.

Majumder, M. T. H., Akter, A., \& Li, X. (2017). Corporate governance and corporate social disclosures: a meta-analytical review. International Journal of Accounting \& Information Management.

Manita, R., Bruna, M. G., Dang, R., \& Houanti, L. H. (2018). Board gender diversity and ESG disclosure: evidence from the USA. Journal of Applied Accounting Research.

Pacy \& Sifuna, A. (2012). Disclose or abstain: the prohibition of insider trading on trial. Journal 
of International Banking Law and Regulation, 27(9), 340.

Post, J. E., Preston, L. E., \& Sauter-Sachs, S. (2002). Redefining the corporation: Stakeholder management and organizational wealth. Stanford University Press.

Rahman, H. U., Zahid, M., \& Khan, M. (2021). Corporate sustainability practices: a new perspective of linking board with firm performance. Total Quality Management \& Business Excellence, $O(0), 1-18$. https://doi.org/10.1080/14783363.2021.1908826

Rahman, H. U., Zahid, M., \& Muhammad, A. (2021). Connecting integrated management system with corporate sustainability and firm performance: from the Malaysian real estate and construction industry perspective. Environment, Development, and Sustainability, 1-25. https://doi.org/10.1007/s10668-021-01538-2

Rooh, Samina \& Malik, M. F. (2021). Empirical Investigation into the impact of Corporate Governance on Stock Returns in Pakistan: Evidence from Financial Sector of Pakistan.

Rooh, S., Hussain, A., \& Zahid, M. (2021). The impact of behavioral factors on environmental issues regarding individual investor's decision making: Empirical evidence from Pakistan's stock market. Sarhad Journal of Management Sciences (SJMS), 7(1), 65-82.

Shakil, M. H., Tasnia, M., \& Mostafiz, M. I. (2020). Board gender diversity and environmental, social and governance performance of US banks: Moderating role of environmental, social and corporate governance controversies. International Journal of Bank Marketing.

Solomon, J. (2020). Corporate governance and accountability. John Wiley \& Sons.

Tawfeeq, T., Alabdullah, Y., Ahmed, E. R., \& Muneerali, M. (2019). Effect of Board Size and Duality on Corporate Social Responsibility: What has Improved in Corporate Governance in Asia? Journal of Accounting Science, 3(2), 121-135. https://doi.org/10.21070/jas.v3i2.2810

Velte, P. (2016). Women on management board and ESG performance. Journal of Global Responsibility.

Weill, L. (2005). Leverage and Corporate Performance: A Frontier Efficiency Analysis on European Countries. SSRN Electronic Journal, 1-20. https://doi.org/10.2139/ssrn.300640

Yolanda, Y., \& Utama, C. A. (2021). Family Ownership Structure, Independent Directors, and Independent Commissioners: Effects on Leverage. Jurnal Manajemen Bisnis, 12(1), 41-55. https://doi.org/10.18196/mabis.v12i1.9525

Zahid, M., Rehman, H. U., Ali, W., Khan, M., Majed Alharthi, Qureshi, M. I., \& Jan, A. (2019). Boardroom gender diversity: Implications for corporate sustainability disclosures in Malaysia. Journal of Cleaner Production, 244(2020), 1-14. https://doi.org/10.1016/j.jclepro.2019.118683

Zahid, M., Rehman, H. U., \& Khan, M. A. (2018). ESG in Focus: The Malaysian Evidence. City University Research Journal, 09(01), 72-84.

Zahid, M., Shad, F., \& Ali, W. (2020). Addressing endogeneity by proposing novel instrumental variables in the nexus of sustainability reporting and firm financial performance: A step-bystep procedure for non- experts. Bus Strat Env., March, 1-18. https://doi.org/10.1002/bse.2559

Zahra, S. A., \& Pearce, J. A. (1989). Boards of directors and corporate financial performance: A review and integrative model. Journal of Management,15(2), 291-334. 